\title{
Seasonal cell differentiation and olfactory potency of secretions by the anal glands of male peacock blenny Salaria Pavo
}

\author{
R. M. Serrano*†, O. Lopesł, P. C. Hubbard*, J. Araújoł, \\ A. V. M. Canário* and E. N. Barata*†§ \\ *CCMAR-CIMAR Laboratório Associado, Universidade do Algarve, Campus de \\ Gambelas, 8005-139 Faro, Portugal, †Departamento de Biologia, Universidade de \\ Évora, Évora, Portugal and \$Centro de Ecologia e Ambiente, Universidade de Évora, \\ apartado 94, 7002-554 Évora, Portugal
}

(Received 18 March 2008, Accepted 11 July 2008)

\begin{abstract}
The current study shows cytological differences between the anal glands of pre-spawning and spawning peacock blennies Salaria pavo. The cytological differences in the anal gland coincide with higher olfactory potency of their secretions in spawning males, suggesting that seasonal differentiation of cell clusters secreting neutral mucins is related to the production and release of the putative sex pheromone.

(C) 2008 The Authors

Journal compilation (C) 2008 The Fisheries Society of the British Isles
\end{abstract}

Key words: Blenniidae; electron microscopy; electro-olfactogram; histochemistry; pheromones; secretory cells.

Although hormonal pheromones are known to affect the reproductive behaviour and physiology of teleosts (Stacey \& Sorensen, 2006), knowledge of specialized tissues producing these pheromones is scarce. In the African catfish Clarias gariepinus (Burchell), black goby Gobius niger L. and round goby Neogobius melanostomus Pallas, accessory testicular glands produce large amounts of steroids and steroid conjugates and, as such, may be involved in pheromone production (Colombo et al., 1980; Lambert \& Resink, 1991; Belanger et al., 2004; Arbuckle et al., 2005). Glands on the fins or gills of male characins have been suggested as a source of sex pheromones (Weitzman \& Fink, 1985; Bushmann et al., 2002; Weitzman et al., 2005). The anal gland, present on the anal fin of some blennies (Blenniidae), is also suggested to be a source of reproductive pheromones (Laumen et al., 1974; Barata et al., 2008; Serrano et al., 2008).

The peacock blenny Salaria pavo (Risso) inhabits the intertidal rocky shores of the Mediterranean Sea and adjacent Atlantic coast (Zander, 1986) and, as

§Author to whom correspondence should be addressed. Tel.: +351289800995 ext. 7389; fax: +351 289800069; email: ebarata@ualg.pt 
is general in blennies, the mating system is polygynandrous. Males defend a territory around a rock cavity (crevice or hole) where females deposit adhesive eggs, and parental care is given exclusively by the male that guards the eggs until hatching (Patzner et al., 1986). As in other blennies, the anal gland of $S$. pavo differentiates from the epidermis of the first two rays of the anal fin (Fishelson, 1963; Patzner et al., 1986; Oliveira et al., 1999) and its seasonal differentiation is apparently dependent on circulating androgens (Laumen et al., 1974; Oliveira et al., 2001). Furthermore, the anal glands are a source of a putative sex pheromone that attracts reproductively competent females and, thereby, enhances male reproductive success (Laumen et al., 1974; Barata et al., 2008; Serrano et al., 2008). In spawning males, the anal gland consists of extensive integument folds bearing a large number of columnar mucinsecreting cells (Giacomello et al., 2006); however, it is unknown whether these cells differentiate only during the spawning season and, thus, are involved in pheromone production and release. The current study investigated whether the secretory cells in the anal gland undergo seasonal differentiation and, if so, whether the olfactory potency of anal gland secretions is related to the presence of these cells.

Salaria pavo breeds from May until September in Ria Formosa (south Portugal, Algarve, $36^{\circ} 59^{\prime} \mathrm{N}$; 7 $7^{\circ} 51^{\prime} \mathrm{W}$ ), an extensive littoral lagoon where males establish nests in the holes of bricks that clam culturists use to delimit their fields (Almada et al., 1994). Male blennies were captured inside these bricks at low tide during pre-spawning (13 males in January, mean \pm s.D., standard length, $L_{\mathrm{S}},=103.2 \pm 5.5 \mathrm{~mm}$; mass, $M,=15.6 \pm 3.4 \mathrm{~g}$ ), spawning (14 males in June to July, $L_{\mathrm{S}}=111.4 \pm 10.5 \mathrm{~mm} ; M=21.9 \pm 6.9 \mathrm{~g}$ ) and postspawning periods (three males in October, $L_{\mathrm{S}}=114.0 \pm 5.6 \mathrm{~mm} ; M=23.2 \pm 1.6 \mathrm{~g}$ ). The males were anaesthetized by immersion in sea water containing $0 \cdot 3 \mathrm{~g}^{-1}$ MS222 (3-aminobenzoic acid ethyl ester; Sigma-Aldrich, St Louis, MO, U.S.A.) and the anal glands and anal-fin rays removed with small scissors, without causing any bleeding. An antiseptic cream (Betadine ${ }^{\circledR}$ ) was applied to the wound and the males were then kept in aquaria for at least 1 week before they were released in the same place as their capture. The mass of anal glands $\left(M_{\mathrm{AG}}\right)$ was normalized to male mass $\left(y=100 M_{\mathrm{AG}} M^{-1}\right)$ and compared among pre-breeding, breeding and post-breeding males by the Kruskal-Wallis test followed by post hoc Dunn's test for multiple comparisons.

Anal glands from pre-spawning, spawning and postspawning males were fixed in either Bouin's fixative for light microscopy or $2.5 \%$ glutaraldehyde in $0 \cdot 1 \mathrm{M}$ cacodylate buffer $(\mathrm{pH} 7 \cdot 4)$ for electron microscopy. For light microscopy (Leitz Dialux 20 microscope; Oberkochen, Germany), anal gland tissue embedded in paraffin was cut into $5 \mu \mathrm{m}$ sections and stained with haematoxylin and eosin (H\&E). For transmission electron microscopy (Philips CM10 electron microscope operating at $80 \mathrm{kV}$; Eindhoven, The Netherlands), anal gland tissues were post-fixed in $1 \%$ osmium tetroxide $(\mathrm{pH} 7 \cdot 4)$ and embedded in Epon 812. Semi-thin $(0 \cdot 5-1 \mu \mathrm{m})$ sections were stained with toluidine blue and methylene blue. Ultra-thin sections were cut and stained with uranyl acetate and lead citrate. Testing for the presence of neutral (periodic acid-Schiff's reaction) and acidic (alcian blue $8 \mathrm{GX}, \mathrm{pH} 2.5$ ) mucins in anal glands from spawning males was as described by Pearse (1985). Surface details of anal 
glands from spawning males were observed under a scanning electron microscope (JEOL, JSM $6400 \mathrm{~F}$; Tokyo, Japan) at $10 \mathrm{kV}$.

The olfactory potency of incubation media of anal glands from pre-spawning and spawning males was assessed by recording electro-olfactograms (EOG) in females (mean \pm S.D., $L_{\mathrm{S}}=78.4 \pm 4.9 \mathrm{~mm} ; M=6.5 \pm 1.2 \mathrm{~g}, n=14$ ). Anal glands and anal-fin rays from six pre-spawning males and from eight spawning males were individually incubated in Costar 24 well plates (Costar Corporation, Cambridge, MA, U.S.A.) at $10 \mathrm{mg}$ of tissue per $\mathrm{ml}$ of culture medium (TBSS; Jalabert \& Fostier, 1984) in an oxygen-enriched atmosphere at $21.0^{\circ} \mathrm{C}$, range $\pm 0 \cdot 2^{\circ} \mathrm{C}$ with gentle agitation for $24 \mathrm{~h}$. Half of the culture medium containing a given type of tissue was then pooled and frozen at $-20^{\circ} \mathrm{C}$ until use. The EOG was recorded in females captured in the Ria Formosa during the breeding season (June to July) as described in Serrano et al. (2008). To lessen the shunting effect of sea water, the females were pre-adapted gradually to dilute sea water (from 35 to 12) for at least 5 days prior to recording. Females were anaesthetized by immersion in water containing $100 \mathrm{mg} 1^{-1}$ MS222 followed by subcutaneous injection of $3 \mu \mathrm{g} \mathrm{g}^{-1} \operatorname{Saffan}^{\mathrm{TM}}$ (Schering-Plough Animal Health, Welwyn Garden City, U.K.), placed on a padded V-clamp and aerated water was pumped over the gills. The olfactory chamber was continually irrigated with diluted (12) sea water via a gravity-fed system which terminated in a stimulus delivery tube positioned in the exhalent nostril. All stimuli were dissolved in diluted (12) sea water and introduced in the flow to the olfactory chamber by a three-way valve. The EOG was recorded differentially using glass electrodes filled with $3 \mathrm{M} \mathrm{NaCl}$ in $1 \%$ agar. The recording electrode was placed inside the inhalant nostril at a position that resulted in the largest response to the standard stimulus $\left(10^{-5} \mathrm{M}\right.$ L-cysteine); the reference electrode was placed lightly on the skin of the head nearby. All females were alive at the end of each experiment and released 1 week later in good condition in the same place as their capture.

Culture media were tested at $0 \cdot 1 \mathrm{mg}$ tissue $\mathrm{ml}^{-1}$ since lower concentrations did not evoke EOG amplitudes consistently higher than those of a blank (stimulus-free background water treated in exactly the same way as stimulus solutions). For each female, responses to a blank and to $10^{-5} \mathrm{M}$ L-cysteine were recorded between groups of related stimuli; the order in which the stimuli were given varied among females. The responses to the culture medium without any tissue (control) were clearly smaller than those to tissue culture media and not considered in the analysis. To normalize the olfactory responses, the mean response of the first and second blank responses was subtracted from each response to tissue culture medium and normalized to the mean of the first and last responses to $10^{-5} \mathrm{M}$ L-cysteine (similarly blank subtracted). The normalized EOG amplitudes evoked by anal glands and anal rays from breeding males (tested on eight and four females, respectively) and pre-breeding males (each tested on six females) were $\log _{10}$-transformed and compared by oneway ANOVA followed by Tukey test for all pair-wise multiple comparisons.

The anal glands of spawning males (mean \pm S.E., $0.18 \pm 0.02 \%, n=13$ ) were larger than those of pre-spawning $(0 \cdot 05 \pm 0 \cdot 01 \%, n=14)$ and postspawning males $(0.05 \pm 0.01 \%, n=3$; Kruskal-Wallis test, d.f. $=2, P<0.001)$. In spawning males, each anal-gland lobe was large and highly folded with 
a grooved surface on which numerous small cavities $(1 \cdot 5-5 \cdot 0 \mu \mathrm{m}$ width) housed apical projections from clusters of secretory cells [Fig. 1 (a)-(d)]; such secretory clusters were $c$. 10 -fold more abundant in spawning males (mean \pm S.E. $8 \cdot 8 \pm$ $0 \cdot 8$ clusters per $\left.350 \mu \mathrm{m}^{2}, n=4\right)$ than in pre-spawning males $(0 \cdot 8 \pm 0 \cdot 2$ clusters per $350 \mu \mathrm{m}^{2}, n=4$ ) and non-existent in postspawning males [Fig. 2 (a)-(c)]. In anal glands from spawning males, only mucous cells stained blue with $\mathrm{AB}$ pH $2 \cdot 5$, however, both mucous and secretory cells stained positively with PAS. When the two treatments were applied together, mucous cells stained blue-purple whereas secretory cells were PAS-reactive only [Fig. 2(d)]. Each secretory cluster consisted of several columnar cells (c. $20 \mu \mathrm{m}$ length) with small (c. $1.5 \mu \mathrm{m}$ length) microvilli protruding into an extracellular space (atrium or pore); outermost (pavement) cells, typical of fish epidermis (Whitear \& Mittal, 1984; Arellano et al., 2004), border the external surface of the anal gland and constituted the upper lateral wall of the secretory atrium (Fig. 3). The secretory cells had numerous electron-dense vesicles $(0 \cdot 3-0.9 \mu \mathrm{m}$ diameter) concentrated
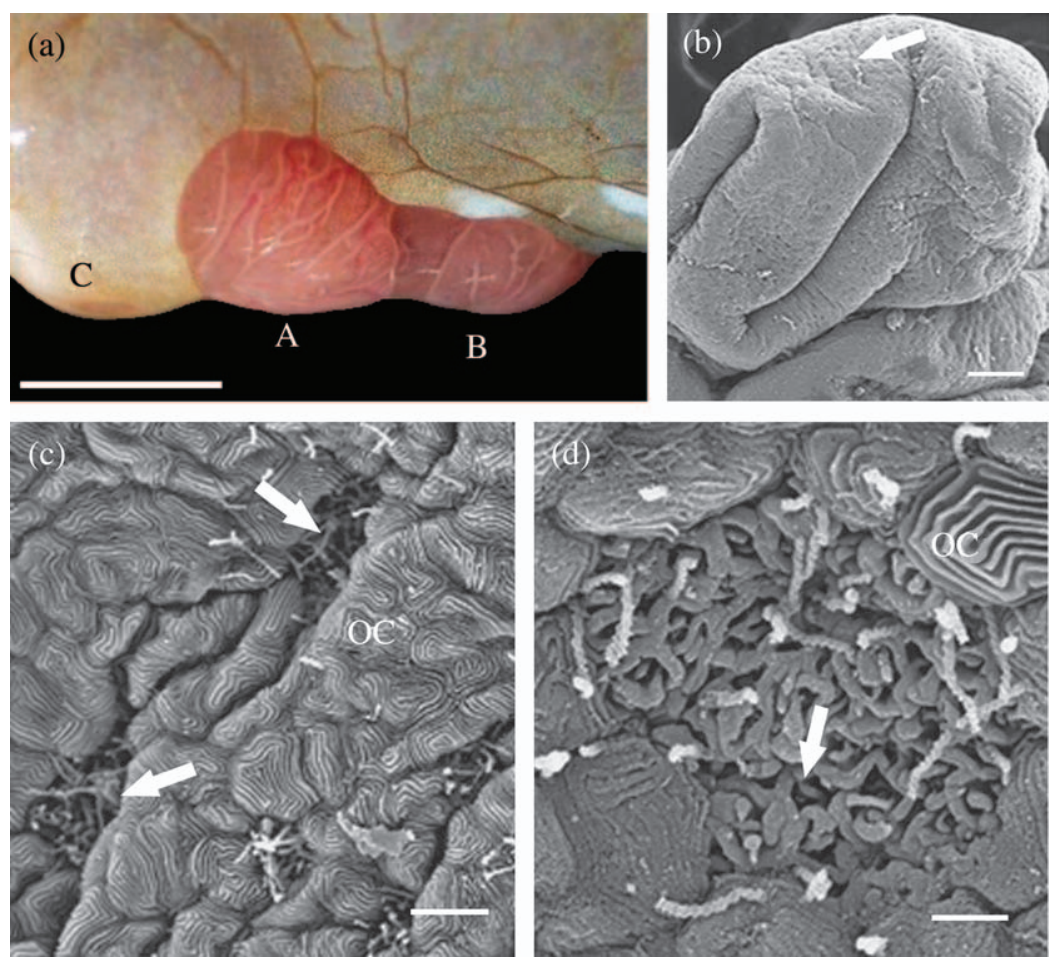

FIG. 1. Photograph and scanning electron microscopy micrographs (SEM) of the anal glands of a Salaria pavo spawning male. (a) Genital area (lateral view) showing the anterior (A) and posterior (B) anal gland lobes located immediately after the genital papilla (C); scale bar $=2 \mathrm{~mm}$. (b) SEM showing anal gland anterior lobe with the surface bearing numerous tiny cavities $(\Longrightarrow$; scale bar $=40 \mu \mathrm{m})$ wherein (c) clusters of secretory cells $(\Longrightarrow)$ are located (OC, outermost epithelial cells with a microridged apical surface) (scale bar $=4 \mu \mathrm{m}$ ). (d) Detail of a cavity housing a cluster of secretory cells $(\Longrightarrow$, microvilli-like protrusions of the apical membrane of secretory cells; OC, outermost epithelial cells) (scale bar $=1 \mu \mathrm{m}$ ). 

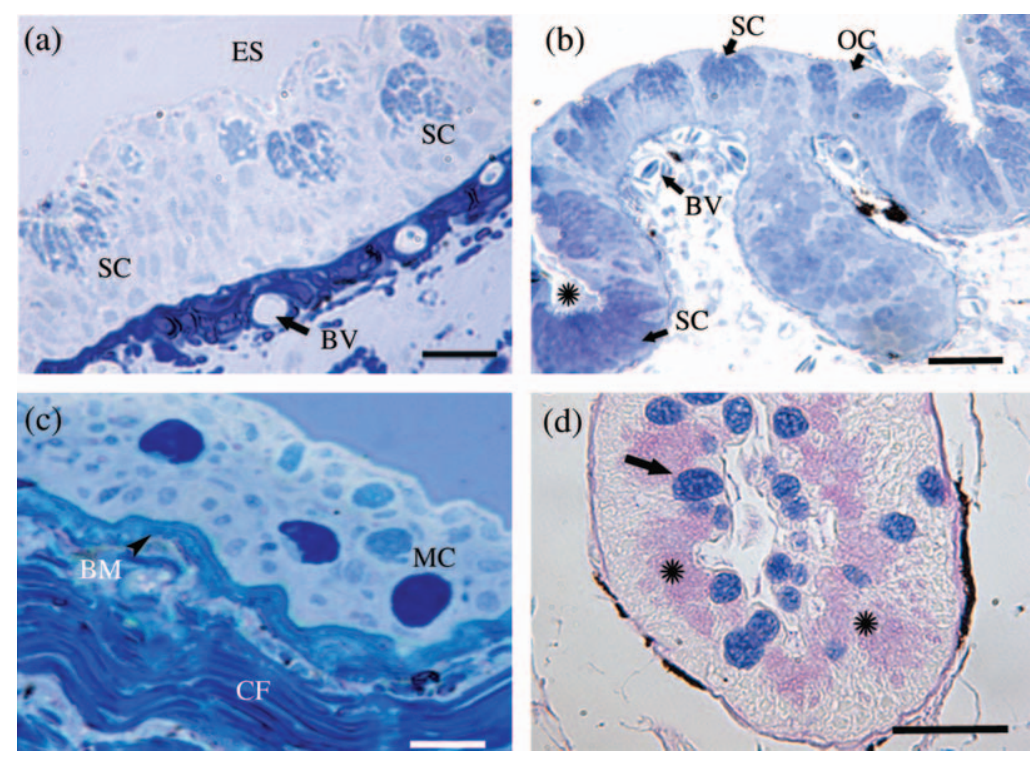

FIG. 2. (a)-(c) Histological sections of Salaria pavo anal glands across the breeding cycle (scale bars $=30$ $\mu \mathrm{m})$. Toluidine blue stained semi-thin sections of anal gland from (a) pre-spawning, (b) spawning and (c) postspawning males. *, secretory atrium; BM, basement membrane; BV, blood vessel; CF, collagen fibres; ES, external space; MC, mucous cells; OC, outermost cells; SC, secretory cells. (d) Mucin-histochemistry [alcian blue (AB) and periodic acid-Schiff (PAS)] of anal glands from spawning males (scale bar $=25 \mu \mathrm{m})$. AB-PAS stained section, showing blue mucous cells $(\rightarrow)$ and pink secretory cells $(*)$.

in the apical region of the cytoplasm, containing a finely granular or lamellar crystalline material; the secretion stored in the vesicles was released apically into the secretory atrium where it formed patches of flocculent-like material (Fig. 3). A well-developed rough endoplasmic reticulum and Golgi complex, and a nucleus rich in euchromatin, with a distinct nucleolus and clumps of electron-dense chromatin on the inner nuclear membrane were all indicative of active protein synthesis and secretion.

EOGs evoked by culture media of anal glands and fin rays were similar in form to those evoked by amino acids, male-conditioned water and macerated anal glands in a previous study (Serrano et al., 2008), and typical of fish EOGs in general. The pooled culture medium of anal glands from spawning males evoked the largest EOG responses in females. The culture medium of anal glands from pre-spawning males evoked larger responses than those of fin rays but the size of responses to fin ray media did not depend on the reproductive status of the donor (Fig. 4).

The current study suggests that cytological differentiation in the anal glands of pre-spawning and spawning males are linked to odorant secretion. The anal glands of spawning males have substantially more secretory cell clusters than those of pre-spawning males and their secretory cells have clear signs of protein synthesis and secretion, including neutral mucins. No firm link, however, can yet be made between glycoprotein secretion and anal-gland odorants. Nevertheless, the odorants released by $S$. pavo anal glands are hydrophilic compounds 


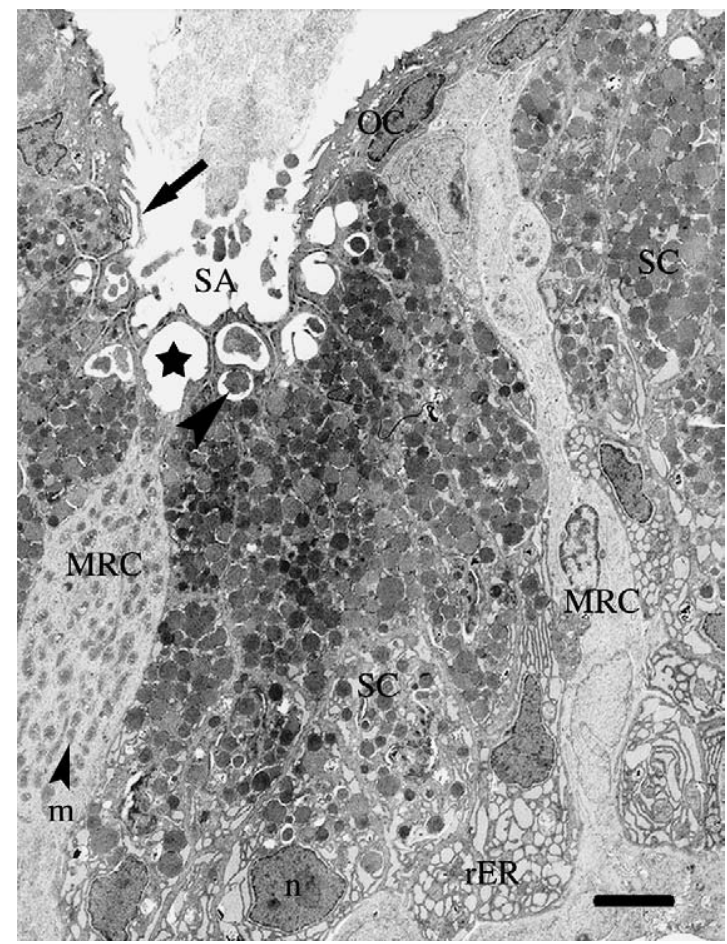

FIG. 3. Transmission electron microscopy micrograph showing secretory cells in anal glands of Salaria pavo spawning males (scale bar $=5 \mu \mathrm{m}$ ). Cluster of secretory cells (SC) with numerous electrondense secretory vesicles; $>$, secretory vesicle in course of exocytosis; $\downarrow$, invagination of the apical secretory cell membrane; $\mathrm{n}$, nucleus of secretory cell; rER, rough endoplasmic reticulum; SA, secretory atrium. $\rightarrow$ microvilli-like protrusions (ridges) of the apical outermost cell (OC) membrane. Note mitochondria-rich cell (MRC), with a light cytoplasm containing numerous mitochondria $(\mathrm{m})$.

mostly $<500 \mathrm{Da}$, but odorants $>10 \mathrm{kDa}$ are also present (Serrano et al., 2008). Amino acids and small peptides, possibly derived from proteins or glycoproteins precursors, may constitute the anal gland odour that attracts sexually active females (Barata et al., 2008; Serrano et al., 2008). Peptide sex pheromones have been either suggested or demonstrated in marine invertebrates (Cummins et al., 2004, 2006; Hardege et al., 2004) and amphibians (Brizzi et al., 2002; Kikuyama et al., 2005). Further research is necessary, however, to determine if, and how, amino acids, peptides or other types of compound contribute to the anal gland pheromone of $S$. pavo.

Club glands on the tip of each dorsal fin ray in mature Lipophrys pholis (L.), also present on the fins of many Mediterranean male blennies during the breeding season (including on $S$. pavo dorsal and caudal fin rays), have a histological organization similar to that of the anal gland, i.e. many groups of tall PASreactive columnar cells surrounding pores that open to the outside through a layer of epidermal cells (Northcott \& Bullock, 1991). Whether these club glands release female attractants, or any type of pheromone, is not yet known. In S. pavo, at least, the anal glands appear to be more important in this respect since their removal decreases female attraction (Laumen et al., 1974; Barata 


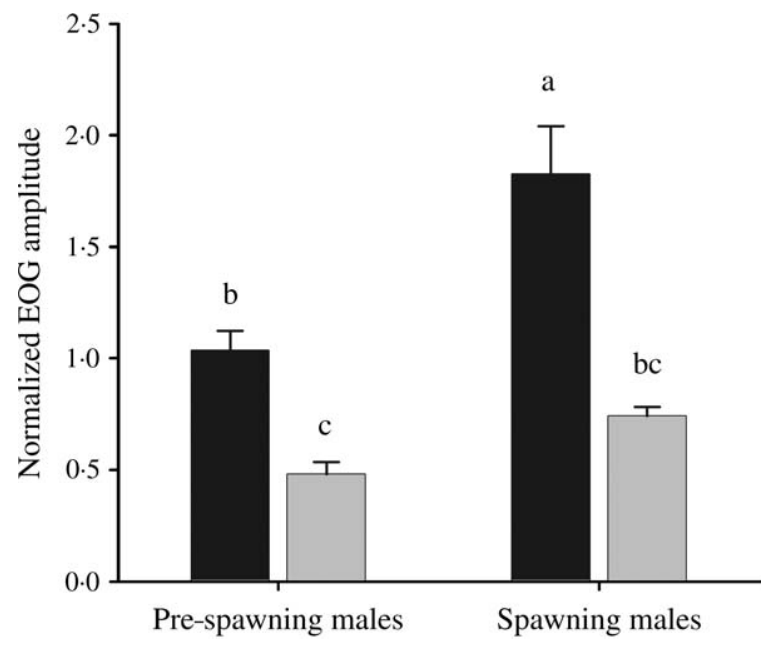

FIG. 4. Olfactory responses of female Salaria pavo to anal glands and fin rays. Normalized electroolfactogram (EOG) amplitudes (mean \pm S.E.) evoked by culture media $\left(0 \cdot 1 \mathrm{mg}\right.$ tissue $\left.\mathrm{ml}^{-1}\right)$ of anal glands $(\square)$ and anal-fin rays $(\square)$ from pre-spawning and spawning males. Different lower case letters above the bars indicate significant differences (Tukey test for all pair-wise multiple comparisons, $P<$ $0 \cdot 05)$.

et al., 2008; Serrano et al., 2008). Whether secretions by the club glands of blennies lacking anal glands are female attractive and whether, in $S$. pavo, anal glands secrete odorants different in both chemical nature and effect from club gland secretions are questions worth addressing in the future. Both the anal glands and club glands have been suggested as sources of antimicrobial agents, which protect the eggs (Zander, 1975; Kotrschal \& Goldschmid, 1983; Northcott \& Bullock, 1991; Giacomello et al., 2006). These two possible functions for anal glands, producers of pheromones (Barata et al., 2008) or antimicrobial agents, are not mutually exclusive; one may have evolved from the other. This, however, will only be clarified when the chemical identities of the active compounds are known.

This work was funded by Ministry of Science and Higher Education and European Social Funds through the Portuguese National Science Foundation (FCT): project POCTI/BSE/45843/2002, and PhD fellowship (SFRH/BD/6670/2001) to R. M. Serrano. We thank M. Nunes (Electron Microscopy Laboratory, Portuguese Cancer Institute, Lisbon) who kindly allowed access to the TEM and helped in the film processing and P. Chaves (Pathological Anatomy Laboratory, Portuguese Cancer Institute, Lisbon) for her advice on histochemistry. We are also grateful to T. Varejão for TEM photographic work and M. Lima for helpful technical support.

\section{References}

Almada, V. C., Gonçalves, E. J., Santos, A. J. \& Baptista, C. (1994). Breeding ecology and nest aggregations in a population of Salaria pavo (Pisces: Blenniidae) in an area where nest sites are very scarce. Journal of Fish Biology 45, 819-830.

Arbuckle, W. J., Belanger, A. J., Corkum, L. D., Zielinski, B. S., Li, W. M., Yun, S. S., Bachynski, S. \& Scott, A. P. (2005). In vitro biosynthesis of novel $5 \beta$-reduced 
steroids by the testis of the round goby, Neogobius melanostomus. General and Comparative Endocrinology 140, 1-13.

Arellano, J. M., Storch, V. \& Sarasquete, C. (2004). Ultrastructural and histochemical study on gills and skin of the Senegal sole, Solea senegalensis. Journal of Applied Ichthyology 20, 452-460.

Barata, E. N., Serrano, R. M., Miranda, A., Nogueira, R., Hubbard, P. C. \& Canário, A. V. M. (2008). Putative pheromones from the anal glands of male blennies attract females and enhance male reproductive success. Animal Behaviour 75, 379-389.

Belanger, A. J., Arbuckle, W. J., Corkum, L. D., Gammon, D. B., Li, W., Scott, A. P. \& Zielinski, B. S. (2004). Behavioural and electrophysiological responses by reproductive female Neogobius melanostomus to odours released by conspecific males. Journal of Fish Biology 65, 933-946.

Brizzi, R., Delfino, G. \& Pellegrini, R. (2002). Specialized mucous glands and their possible adaptive role in the males of some species of Rana (Amphibia, Anura). Journal of Morphology 254, 328-341.

Bushmann, P. J., Burns, J. R. \& Weitzman, S. H. (2002). Gill-derived glands in glandulocaudine fishes (Teleostei: Characidae: Glandulocaudinae). Journal of Morphology 253, 187-195.

Colombo, L., Marconato, A., Belvedere, P. C. \& Frisco, C. (1980). Endocrinology of teleost reproduction. A testicular steroid pheromone in the black goby, Gobius jozo L. Bollettino Zoologico 47, 355-364.

Cummins, S. F., Nichols, A. E., Rajarathnam, K. \& Nagle, G. T. (2004). A conserved heptapeptide sequence in the waterborne attractin pheromone stimulates mate attraction in Aplysia. Peptides 25, 185-189.

Cummins, S. F., Nichols, A. E., Schein, C. H. \& Nagle, G. T. (2006). Newly identified water-borne protein pheromones interact with attractin to stimulate mate attraction in Aplysia. Peptides 27, 597-606.

Fishelson, L. (1963). Observations on littoral fishes of Israel. 1. Behaviour of Blennius pavo Risso (Telefostei, Blenniidae). Israel Journal of Zoology 12, 67-79.

Giacomello, E., Marchini, D. \& Rasotto, M. (2006). A male sexually dimorphic trait provides antimicrobials to eggs in blenny fish. Biology Letters 2, 330-333.

Hardege, J. D., Bartels-Hardege, H., Muller, C. T. \& Beckmann, M. (2004). Peptide pheromones in female Nereis succinea. Peptides 25, 1517-1522.

Jalabert, B. \& Fostier, A. (1984). The follicular sensitivity in vitro to maturation-inducing hormones in rainbow trout, Salmo gairdneri. Role of oestradiol-17-beta. Aquaculture 43, 1-11.

Kikuyama, S., Nakada, T., Toyoda, F., Iwata, T., Yamamoto, K. \& Conlon, J. M. (2005). Amphibian pheromones and endocrine control of their secretion. Annals of the New York Academy of Sciences 1040, 123-130.

Kotrschal, K. \& Goldschmid, A. (1983). Aberrant morphology of anal-fin glands in Blennius gattorugine L. (Teleostei: Perciformes: Blenniidae). Zoologischer Anzeiger, Jena 210, 333-339.

Lambert, J. G. D. \& Resink, J. W. (1991). Steroid glucuronides as male pheromones in the reproduction of the African catfish Clarias gariepinus - a brief review. The Journal of Steroid Biochemistry and Molecular Biology 40, 549-556.

Laumen, J., Pern, U. \& Blüm, V. (1974). Investigations on the function and hormonal regulation of the anal appendices in Blennius pavo (Risso). Journal of Experimental Zoology 190, 47-56.

Northcott, S. J. \& Bullock, A. M. (1991). The morphology of the club glands on the dorsal fin of mature male shannies, Lipophrys pholis (L.) (Blenniidae, Teleostei). Journal of Fish Biology 39, 795-806.

Oliveira, R. F., Almada, V., Forsgren, E. \& Gonçalves, E. J. (1999). Temporal variation in male traits, nesting aggregations and mating success in the peacock blenny. Journal of Fish Biology 54, 499-512.

Oliveira, R. F., Carneiro, L. A. \& Canário, A. V. M. (2001). Effects of androgens on social behaviour and morphology of alternative reproductive males of Azorean rock-pool blenny. Hormones and Behavior 39, 157-166. 
Patzner, R. A., Seiwald, M., Adlgasser, M. \& Kaurin, G. (1986). The reproduction of Blennius pavo. 5. Reproductive behavior in natural environment. Zoologischer Anzeiger, Jena 216, 338-350.

Pearse, A. G. E. (1985). Histochemistry, Theoretical and Applied. New York: Churchill Livingstone.

Serrano, R. M., Barata, E. N., Birkett, M. A., Hubbard, P. C., Guerreiro, P. S. \& Canário, A. V. M. (2008). Behavioral and olfactory responses of female Salaria pavo (Pisces: Blenniidae) to a putative multi-component male pheromone. Journal of Chemical Ecology 34, 647-658.

Stacey, N. \& Sorensen, P. (2006). Reproductive pheromones. In Behaviour and Physiology of Fish (Sloman, K. A., Wilson, R. W. \& Balshine, S., eds), pp. 359-412. London: Academic Press.

Weitzman, S. H. \& Fink, S. V. (1985). Xenurobryconin Phylogeny and Putative Pheromone Pumps in Glandulocaudine Fishes (Teleostei: Characidae). Washington, DC: Smithsonian Institution.

Weitzman, S. H., Menezes, N. A., Evers, H.-G. \& Burns, J. R. (2005). Putative relationships among inseminating and externally fertilizing characids, with a description of a new genus and species of Brazilian inseminating fish bearing an anal-fin gland in males (Characiformes: Characidae). Neotropical Ichthyology $\mathbf{3}$, 329-360.

Whitear, M. \& Mittal, A. K. (1984). Surface secretions of the skin of Blennius (Lipophyrys) pholis L. Journal of Fish Biology 25, 317-331.

Zander, C. D. (1975). Secondary sex characteristics of blennioid fishes (Perciformes). Pubblicazioni della Stazione Zoologica di Napoli 39, 717-727.

Zander, C. D. (1986). Blenniidae. In Fishes of the Northeastern Atlantic and the Mediterranean (Whitehead, P. J. P., Bauchot, M. L., Hureau, J. C., Nielsen, J. \& Tortonese, E., eds), pp. 1096-1112. Paris: UNESCO. 